\title{
Perception of Teenage Internet Users on Cyber Crimes \\ (An Empirical Examination on Intermediate College Level Students in Guntur District of A.P)
}

\author{
Satish Kumar Ganta, K.I.Pavan Kumar
}

\begin{abstract}
The dependence and behavior of the citizens on information security and internet activities deeply affect the route that intend for using the information technology. It is a well known factor that the growth of cyber crimes in India is a resultant factor of issues such as lack of proper training and education and the low awareness levels of Indians towards punishment for cyber crimes. This paper aims at studying the perception levels of teenage internet users towards the aspect of cyber crimes based on statutory and ethical perspectives. Descriptive research design was adopted for this study in the sample size was fixed at 120 involving the intermediate college level students of Guntur district in Andhra Pradesh. The data analysis was carried out with the help of statistical tools like $t$-Test and ANOVA. The findings of the study shows that there is no difference in the perception levels among male and female teenage internet users and the study further shows that there exists the significant difference in the perception levels of the respondents based on their level of education and perspectives based on statutory and ethical issues.
\end{abstract}

Key Words : Cyber Crimes, Perception, Cyber Law, Internet Users

\section{INTRODUCTION}

Computer crime, or cybercrime in India has been evolving rapidly in the 21 st century. Technical support scams, along with impersonation of the IRS, are among the most common forms of confidence tricks used in order to receive money from unsuspecting victims. The Information Technology Act, 2000, passed by the Parliament of India in May 2000, had aimed to curb cyber crimes and to provide a legal framework for e-commerce transactions. In 2001, India and United States had set up an India-US cyber security forum as part of a counter-terrorism dialogue.

As the technological advancement is growing by leaps and bounds in India, the vulnerabilities associated with this burgeoning cyberspace is surfacing and its repercussions in the recent times have been witnessed far and wide. Looking at the levitating statistics of cybercrime incidences in India, it cannot be denied that the computer technology poses innumerable internal and external threats.

Revised Manuscript Received on October 15, 2019.

Satish Kumar Ganta, Research Scholar, KLU College of Law, KL University, A.P.

Dr.K.I.Pavan Kumar, Assoc.Professor, KLU College of Law, KL University, A.P.
The proliferation of computer technology has created a new class of threats -"cyber threats"- which societies must confront. These cyber threats can be generically defined as using computer technology to engage in activity that undermines a society's ability to maintain internal or external order. One common definition describes cybercrime as any activity in which computers or networks are a tool, a target or a place of criminal activity

\section{STATEMENT OF THE PROBLEM}

In the present day circumstances, many individuals are becoming the victims of cyber crimes around the globe. For an offence under the aspect of cyber crimes to occur, the criminal just requires a computer and the accessibility towards internet. Cyber crimes paved the way for the occurrence of hacking, identity thefts, frauds pertaining to credit and debit cards, advent of cyber terrorism and related crimes. Cyber crimes may occur at any place and to any one if the personal information are data is lodged in the network system. Generally the hackers who commit cyber crimes around the world are at their teenage levels and their perception towards the cyber crimes differ by basing on personal profiles and their level knowledge towards internet systems. Hence, there is every need to monitor the perception levels of teenage youth with regard to their awareness towards cyber crimes and assorted activities.

\section{OBJECTIVES}

1. To study the perception of teenage internet users on cyber crimes based on statutory and ethical perspectives.

2. To study the difference in the perception levels of teenage internet users based on their gender and level of study.

\section{RESEARCH METHODOLOGY}

For the purpose of this research study, Descriptive Research design was adopted. Primary data was collected with the help of a Structured Questionnaire. The sample respondents were drawn from the students studying at Intermediate College level in Guntur District of Andhra Pradesh. Random Sampling Technique was followed for drawing the sample from the identified universe. 
A total sample of 120 respondents were drawn from Guntur district. Among the sample respondents drawn for the study, 80 respondents were males and 40 respondents were females. Statistical tests like t-Test and ANOVA were used to test the statistical significance of the variables of the study.

The identified variables for this study are perceptions based on Statutory perspectives and perceptions based on ethical perspectives.

\section{DATA ANALYSIS AND DISCUSSION}

Table No. 1

Gender Details of the Sample Respondents

\begin{tabular}{|l|l|l|}
\hline Gender & No. of Respondents & Percentage \\
\hline Males & 80 & 66.7 \\
\hline Females & 40 & 33.3 \\
\hline Total & 120 & 100 \\
\hline
\end{tabular}

Table No.3

t-Test results

Students perception on Cyber Crimes - Gender Vs Statutory and Ethical perspectives

\begin{tabular}{|c|c|c|c|c|c|}
\hline \multirow{2}{*}{ Perspectives } & Gender & $\mathrm{N}$ & $\bar{X}$ & $\mathrm{~F}$ & Sig. \\
\hline \multirow{2}{*}{ Statutory } & Females & 40 & 85.32 & 0.029 & $0.012^{*}$ \\
\cline { 2 - 4 } & Males & 80 & 81.14 & & \\
\hline \multirow{2}{*}{ Ethical } & Females & 40 & 82.76 & \multirow{2}{*}{0.046} \\
\cline { 2 - 4 } & Males & 80 & 79.63 & & \\
\hline
\end{tabular}

$* \mathrm{p}<0.05$ level of significance
The above table shows the t-Test results for the students perception on cyber crimes by examining the factors of gender, statutory perspectives and ethical perspectives. The statistical values for students statutory perspective of cyber crime based on the gender was found $\mathrm{p}<0.05$ which shows that gender can play an important role on statutory perspectives. With regard to the aspect of ethical perspectives of cyber crimes based on gender, it was found p $>0.05$ which means that gender plays less significant role on ethical perspectives.

Table No.4

ANOVA test results

Students perception on Cyber Crimes - Level of Education Vs Statutory and Ethical Perspectives

\begin{tabular}{|l|l|l|l|l|l|}
\hline Perspectives & $\begin{array}{l}\text { Level of } \\
\text { Education }\end{array}$ & $\mathrm{N}$ & $\bar{X}$ & $\mathrm{~F}$ & Sig. \\
\hline Statutory & Jr. Level & 50 & 78.92 & 0.286 & $0.682 *$ \\
\cline { 2 - 4 } & Sr. level & 70 & 76.38 & & \\
\hline \multirow{2}{*}{ Ethical } & Jr. Level & 50 & 74.28 & 0.362 & $0.614^{*}$ \\
\cline { 2 - 4 } & Sr/level & 70 & 77.44 & & \\
\hline
\end{tabular}

$* \mathrm{p}>0.05$ level of significance
The above table shows the gender details of the sample respondents. It shows that 66.7 percent of the total respondents are males and 33.3 percent of the respondents are females.

Table No. 2

Education Details of the Sample Respondents

\begin{tabular}{|l|l|l|}
\hline Level of Education & No. of Respondents & Percentage \\
\hline $\begin{array}{l}\text { Junior } \\
\text { Intermediate }\end{array}$ & 50 & 41.7 \\
\hline $\begin{array}{l}\text { Senior } \\
\text { Intermediate }\end{array}$ & 70 & 58.3 \\
\hline Total & 120 & 100 \\
\hline
\end{tabular}

The above table shows the education details of the sample respondents. It shows that 41.7 percent of the total respondents are in their junior intermediate level of education and 58.3 percent of the respondents are in their senior intermediate level of education.
The above table shows the ANOVA Test results for the students perception on cyber crimes by examining the factors of level of education, statutory perspectives and ethical perspectives. The statistical results shows that $p>0.05$ and it was found that student s statutory and ethical perceptions of cyber crime based on their level of education has significant difference and particularly the senior level students differ significantly in this aspect.

\section{CONCLUSION}

The findings of the study shows that the students at the intermediate collegiate level are aware of cyber crimes up to some extent and among them the senior level students are more aware than their counter part with regard to the aspects of cyber crime. It was further observed that there is no significance difference between the statutory and ethical perspectives among the students. It was further observed that there is no significant difference among the male and female students with regard to the perception towards the perspectives of cyber crime. Hence, the teenaged internet users must be made aware of the aspects of cyber crimes and they should be imparted with sound information on cyber law and penal provisions for committing cyber crimes. 


\section{REFERENCES}

1. Lyman, J., 2002, In Search of the World's Costliest Computer Virus, http://www.newsfactor.com/perl/story/16407.html. 2002.

2. D‘Amico, A., 2000, What Does a Computer Security Breach Really Cost?, The Sans Institute

3. Naik, K. D. Live in Relationship: Social Evil or New Way of Life? Measuring Post Graduate College Students' perception with Special Reference to Vadodara city.

4. Hancock, B., 2002, Security Crisis Management-The Basics, Computers \& Security, 21(5): 397-401.

5. Das, S., \& Kumar, S. Applying RCM Techniques to Household Consumer Durables through the Internet of Things.

6. Nilkund Aseef, Pamela Davis, Manish Mittal, Khaled Sedky, Ahmed Tolba (2005), Cyber-Criminal Activity and Analysis,White Paper, Group 2.

7. Sherasiya, T., Upadhyay, H., \& Patel, H. B. (2016). A survey: Intrusion detection system for internet of things. International Journal of Computer Science and Engineering (IJCSE), 5(2).

8. Stephen Northcutt et al. (2011), Security Predictions 2012 \& 2013 - The Emerging Security Threat

9. Yang, H. L., \& Wu, W. P. (2016). The Effects of Consumers' Belief regarding Internet Rumors on Purchasese Intention from Different Spreading Channels. International Journal of Information Systems, Management Research \& Development (IJISMRD), 6(1), 1-8. 